\title{
Lintupajun suojakaistakokeen valumatuloksia 20 vuoden ajalta
}

Jaana Uusi-Kämppä ja Lauri Jauhiainen

MTT, Kasvintuotannon tutkimus 31600 Jokioinen, etunimi.sukunimi(at)mtt.fi

\section{Tiivistelmä}

Suojakaistatutkimus alkoi MTT:ssä, kun Lintupajun 6-ruutuinen pintavaluntakenttä $(0,7$ ha) perustettiin Jokioisille vuonna 1991. Kentällä on tutkittu $10 \mathrm{~m}$ leveän niittämällä hoidetun nurmikaistan ja luonnonkasveja kasvavan luonnonkaistan kykyä poistaa eroosioainesta sekä ravinteita savimaan pintavalumavesistä. Kaistojen yläpuolella olevaa peltoaluetta on viljelty perinteisellä tavalla (kyntö syksyllä, muokkaus ja kylvö keväällä; 1991-2002), laidunnettu (0,2-0,6 ey/ha; 2003-2005) ja kylvetty suorakylvömenetelmällä (ilman muokkausta; 2006-2013). Pintavalumista on mitattu mm. haihdutusjäännös, joka kuvaa eroosioainesta, kokonaisfosfori (kok-P), maa-ainekseen sitoutunut partikkeli-P (PP), veteen liuennut P (liuk-P), kokonaistyppi (kok-N) ja nitraatti-N. Suojakaistaruuduilta saatuja tuloksia on verrattu ilman kaistaa viljeltyyn ruutuun.

Suurin eroosio $(1100 \mathrm{~kg} / \mathrm{ha} / \mathrm{v})$ mitattiin ilman suojakaistaa perinteisellä tavalla viljeltäessä, mutta suojakaista puolitti kuormituksen. Ilman suojakaistaa viljellyllä suorakylvömaalla eroosio (460 $\mathrm{kg} / \mathrm{ha} / \mathrm{v}$ ) oli yhtä suuri kuin kyntömaalla, jossa oli suojakaista. Suorakylvössä suojakaista vähensi eroosiota noin $30 \%$. Laitumella eroosio $(270 \mathrm{~kg} / \mathrm{ha} / \mathrm{v})$ oli vähäistä.

Viljelytavan ja suojakaistan vaikutus kok-P- ja PP-kuormaan oli samanlainen kuin eroosioon. Eniten kok-P:a (1,0 kg ha/v) ja PP:a $(0,87 \mathrm{~kg} / \mathrm{ha} / \mathrm{v})$ mitattiin perinteisesti viljeltäessä, kun suojakaista puuttui. Kaista vähensi kuormitusta kok-P:n osalta 27-36 \% ja PP:n osalta 44-46 \%. Suorakylvössä kok-P-kuorma oli $0,8 \mathrm{~kg} / \mathrm{ha} / \mathrm{v}$, josta suojakaista poisti $19 \%$. Vastaava PP-kuorma oli $0,54 \mathrm{~kg} / \mathrm{ha} / \mathrm{v}$, josta suojakaista poisti vajaan kolmanneksen. Laitumella kok-P-kuormitus oli samaa suuruusluokkaa kuin suorakylvössä, mutta laitumen PP-kuorma oli noin 40 \% pienempi.

Sen sijaan liuk-P poikkesi PP:sta ja kok-P:sta. Laitumelta mitattiin suurin liuk-P:n määrä $(0,44$ $\mathrm{kg} / \mathrm{ha} / \mathrm{v}$ ), jota nurmikaista vähensi $18 \%$ ja luonnonkaista $36 \%$. Myös suorakylvössä liuk-P:n kuorma oli suuri $(0,24-0,26 \mathrm{~kg} / \mathrm{ha} / \mathrm{v})$, mutta suojakaista ei vähentänyt sitä. Perinteisesti viljellyllä maalla kuormitus $(0,15 \mathrm{~kg} / \mathrm{ha} / \mathrm{v})$ oli pienin. Hoitamaton luonnonkaista lisäsi kyntömaalla liuk-P:n määrää 60 $\%$, mutta vuosittain niitetyllä nurmikaistalla ei ollut vaikutusta.

Perinteisesti viljeltäessä mitattiin suurin kok-N-kuorma $(6,6 \mathrm{~kg} / \mathrm{ha} / \mathrm{v})$, jonka suojakaista puolitti. Suorakylvömaalla ja laitumella kok-N-kuorma oli pari kiloa, josta suojakaista poisti 15-35\%. Typpi oli pääasiassa nitraatti-N:ä.

Suojakaistasta oli hyötyä erityisesti kyntömaalla eroosion torjunnassa sekä PP:n ja kok-P:n kuormituksen vähentämisessä. Suorakylvössä eroosio oli yhtä suuri kuin perinteisesti viljellyllä maalla, jossa oli suojakaista. Liuk-P:a oli eniten laitumen pintavalunnassa, mikä selittynee lannoitteen ja laiduntaneiden lehmien sonnan fosforilla sekä kuolleista kasvisoluista keväällä vapautuneella fosforilla. Suojakaista ei vähentänyt liuk-P:n kuormaa suorakylvössä tai laitumella.

\section{Asiasanat}

Eroosio, fosfori, hajakuormitus, laitumet, muokkaaminen, pintavalunta, suojavyöhykkeet, suorakylvö, typpi 


\section{Johdanto}

Kapeita kolmen metrin levyisiä suojakaistoja sekä leveitä yli 15 metrin suojavyöhykkeitä jätetään pellon ja vesistön väliin estämään pintavalunnan mukana kulkeutuvan maa-aineksen sekä siihen sitoutuneiden aineiden ja liukoisessa muodossa kulkeutuvien yhdisteiden pääsyä vesistöön. Suojakaista ja -vyöhyke toimivat usealla eri tavalla. Ensinnäkin lannoitteen, lannan ja torjunta-aineiden levittämisen vesistön välittömään läheisyyteen estyy, koska niiden levittäminen on kielletty suojakaistalle tai -vyöhykkeelle. Monivuotinen kasvipeite vähentää eroosiota viettävällä maalla. Se myös hidastaa veden virtausnopeutta, jolloin maa-ainesta ehtii sedimentoitua eli laskeutua vyöhykkeelle. Lisäksi kasvit käyttävät osan pellolta veden mukana virranneista ravinteista. Erilaisten suojakaistojen tehoa on tutkittu MTT:ssä Lintupajun peltolohkolle perustetulla koekentällä Jokioisissa vuodesta 1991 lähtien.

\section{Aineisto ja menetelmät}

Lintupajun pintavaluntakenttä (0,7 ha) perustettiin 1980-1990-luvun vaihteessa. Alue jaettiin kuuteen lohkoon, joiden alaosa on yli 10 prosenttia viettävässä rinteessä (Uusi-Kämppä ja Kilpinen 2000). Keväällä 1991 perustettiin kaksi 10 metriä leveätä nurmikaistaa rinteeseen. Kesällä kahden ruudun alaosaan kylvettiin luonnonvaraisia kasveja ja syksyllä istutettiin lehtipuiden sekä pensaiden taimia (luonnonkaista). Nurmikaistan kasvusto niitettiin ja korjattiin vuosittain, mutta luonnonkaistaa ei niitetty. Kahden ruudun alaosaa viljeltiin samalla tavalla kuin rinnealueen yläpuolella olevaa peltoaluetta (ei suojakaistaa).

Pelto kynnettiin syksyllä ja seuraavana keväänä maa muokattiin kylvökuntoon sekä kevätvilja kylvettiin (tavanomainen viljely) vuosina 1991-2001. Kevennettyä muokkausta kokeiltiin syksyllä 1996 ja 1997. Keväällä 2002 kylvettiin nurmensiemen suojaviljan kanssa pellolle, joten syksyllä peltoa ei enää kynnetty. Kesällä 2003 alkoi 3-vuotinen laidunnuskoe, jossa laidunnettiin myös ilman suojakaistaa viljeltyjen ruutujen alaosa. Laidunnuspaine oli 72, 234 ja 128 laidunpäivää/ha/v vuosina 2003-2005. Fosforilannoitetta $(6 \mathrm{~kg} / \mathrm{ha})$ levitettiin kokeen aikana kerran nurmen pintaan. Syksyllä 2005 peltoalueen nurmi tuhottiin glyfosaatilla, mutta ilman suojakaistaa viljeltyjen ruutujen rinnealue ruiskutettiin vasta seuraavana syksynä. Vuodesta 2006 asti kentällä on viljelty viljaa suorakylvömenetelmällä. Syksyllä 2006 kylvettiin syysvehnä ohran jälkeen. Naudan lietelantaa levitettiin $20 \mathrm{t} / \mathrm{ha}$ syksyllä 2006 ja 60 tn/ha keväällä 2008, ja se mullattiin levitystä seuraavana päivänä suorakylvökoneella. Suorakylvökokeen aikana maata ei muokattu. Lannoitustiedot ja viljelyhistoria on esitetty tarkemmin julkaisuissa Uusi-Kämppä ja Kilpinen (2000) ja Uusi-Kämppä ja Jauhiainen (2010).

Koealueen pintavalunta kerättiin $9 \mathrm{~m}$ leveillä keräimillä, jotka ulottuivat jankkoon asti. Pintavalunta johdettiin mittausrakennukseen, jossa mitattiin kunkin ruudun valunta ja kerättiin valumapainotteiset vesinäytteet. Näytteistä analysoitiin laboratoriossa haihdutusjäännös (HJ), joka kuvaa eroosiota, liukoinen (liuk-P) ja kokonaisfosfori (kok-P) sekä nitraatti-, ammonium- ja kokonaistyppi $\left(\mathrm{NO}_{3}{ }^{-} \mathrm{N}\right.$, $\mathrm{NH}_{4}{ }^{+}$-N, kok-N) SFS-standardien mukaisesti. Partikkelifosforin (PP) pitoisuus laskettiin vähentämällä kok-P:sta liuk-P:n pitoisuus. Salaojavettä ei ollut mahdollista kerätä kentältä. Pellolta ja suojakaistoilta otettiin myös maanäytteitä eri maakerroksista $(0-2,2-5,5-10,10-20 \mathrm{~cm})$ helppoliukoisen fosforin määrityksiä varten.

\section{Tulokset ja tulosten tarkastelu}

\section{Eroosioaineksen ja siihen sitoutuneen fosforin määrät}

Eroosio oli suurinta $(1100 \mathrm{~kg} / \mathrm{ha} / \mathrm{v})$ perinteisellä tavalla viljeltäessä, jossa pelto kynnettiin syksyllä ja äestettiin kylvökuntoon keväällä (taulukko 1). Suojakaistat puolittivat kuormituksen. Maan jättäminen sängelle talven ajaksi vähensi tehokkaasti eroosiota syksyllä ja keväällä. Myös maan pintaan jääneet puintitähteet suojasivat maata eroosiolta. Suorakylvökokeessa suojakaista vähensi eroosiota noin 30 $\%$. Laitumella eroosio $(270 \mathrm{~kg} / \mathrm{ha} / \mathrm{v})$ oli vähäistä. Suojavyöhykkeen laiduntaminen ei tilastollisesti lisännyt eroosiota tai fosforikuormitusta niittoon verrattuna (Uusi-Kämppä \& Jauhiainen 2010). Lehmien laiduntaminen kuitenkin tiivisti maata, josta saattaa seurata pintavalunnan lisääntyminen (Rasa \& Eickhorst 2012).

Viljelytavan ja suojakaistan vaikutus kok-P- ja PP-kuormitukseen oli samanlainen kuin eroosioon. Eniten kok-P:a (1,0 kg ha/v) ja PP:a $(0,87 \mathrm{~kg} / \mathrm{ha} / \mathrm{v})$ mitattiin perinteisellä tavalla viljeltäessä, kun pellon alareunasta puuttui suojakaista (taulukko 1). Suojakaista pienensi kok-P:n kuormaa 27-36 \% ja PP:n kuormaa 44-46 \%. Suorakylvökokeessa kok-P-kuorma $(0,8 \mathrm{~kg} / \mathrm{ha} / \mathrm{v})$ ja PP-kuorma $(0,54$ $\mathrm{kg} / \mathrm{ha} / \mathrm{v}$ ) olivat samaa suuruusluokkaa kuin perinteisesti viljeltäessä, kun suojakaista oli käytössä. Suo- 
rakylvössä suojakaista pienensi kok-P-kuormitusta $19 \%$ ja PP-kuormitusta $30 \%$. Laitumella kok-Pkuormitus oli $10 \%$ pienempi ja PP-kuorma $40 \%$ pienempi kuin suorakylvössä.

Partikkelifosforin kuormituksen väheneminen viljelymenetelmän ja suojakaistan ansiosta oli samanlainen kuin eroosioaineksella, koska PP kulkeutuu eroosioaineksen mukana. Sen sijaan kok-P:n kuomitukseen suojakaistalla ja viljelytavalla oli pienempi merkitys, koska kokonaisfosforiin sisältyi PP:n lisäksi liukoinen fosfori. Päinvastoin kuin PP liukoinen fosfori lisääntyi suojakaistan tai kasvipeitteisyyden takia.

Taulukko 1. Pintavalunta, haihdutusjäännös (HJ), kokonaisfosfori (Kok-P), liukoinen P (Liuk-P), partikkeli-P (PP), kokonaistyppi (Kok-N), nitraatti- $\left(\mathrm{NO}_{3}{ }^{-} \mathrm{N}\right)$ ja ammoniumtyppi $\left(\mathrm{NH}_{4}{ }^{+}-\mathrm{N}\right)$ ilman suoja kaistaa, nurmikaistan tai luonnonkaistan kanssa viljeltäessä perinteisellä tavalla (1991-2002), suorakylvössä (2006-2012) ja laidunnettaessa (2003-2005).

\begin{tabular}{|l|l|l|l|l|l|l|l|l|l|}
\hline Kuorma & \multicolumn{2}{|c|}{$\begin{array}{l}\text { Perinteinen viljely (kyntö + äestys } \\
\text { ja kevätkylvö; 1991-2002) }\end{array}$} & \multicolumn{3}{c|}{ Suorakylvö (2006-2012) } & \multicolumn{3}{c|}{ Laidun (2003-2005) } \\
\hline & $\begin{array}{l}\text { Ei suo- } \\
\text { jakaistaa }\end{array}$ & $\begin{array}{l}\text { Nurmi- } \\
\text { kaista }\end{array}$ & $\begin{array}{l}\text { Luonnon- } \\
\text { kaista }\end{array}$ & $\begin{array}{l}\text { Ei suo- } \\
\text { jakaistaa }\end{array}$ & $\begin{array}{l}\text { Nurmi- } \\
\text { kaista }\end{array}$ & $\begin{array}{l}\text { Luonnon- } \\
\text { kaista }\end{array}$ & $\begin{array}{l}\text { Ei suo- } \\
\text { jakaistaa }\end{array}$ & $\begin{array}{l}\text { Nurmi- } \\
\text { kaista }\end{array}$ & $\begin{array}{l}\text { Luonnon- } \\
\text { kaista }\end{array}$ \\
\hline $\begin{array}{l}\text { Pintava- } \\
\text { lunta, } \\
\mathrm{mm}\end{array}$ & 140 & 110 & 130 & 130 & 120 & 100 & 120 & 110 & 100 \\
\hline $\begin{array}{l}\mathrm{HJ} \\
\mathrm{kg} / \mathrm{ha}\end{array}$ & 1100 & 500 & 450 & 460 & 330 & 300 & 270 & 240 & 230 \\
\hline $\begin{array}{l}\text { Kok-P, } \\
\mathrm{kg} / \mathrm{ha}\end{array}$ & 1,02 & 0,65 & 0,74 & 0,79 & 0,64 & 0,64 & 0,70 & 0,61 & 0,56 \\
\hline $\begin{array}{l}\mathrm{Liuk}-\mathrm{P}, \\
\mathrm{kg} / \mathrm{ha}\end{array}$ & 0,15 & 0,14 & 0,24 & 0,25 & 0,24 & 0,26 & 0,44 & 0,36 & 0,28 \\
\hline $\begin{array}{l}\mathrm{PP}, \\
\mathrm{kg} / \mathrm{ha}\end{array}$ & 0,87 & 0,49 & 0,48 & 0,54 & 0,40 & 0,38 & 0,30 & 0,27 & 0,32 \\
\hline $\begin{array}{l}\mathrm{Kok}-\mathrm{N}, \\
\mathrm{kg} / \mathrm{ha}\end{array}$ & 6,6 & 2,5 & 3,4 & 2,0 & 1,3 & 1,3 & 1,8 & 1,5 & 1,5 \\
\hline $\begin{array}{l}\mathrm{NO}_{3}{ }^{-}-\mathrm{N}, \\
\mathrm{kg} / \mathrm{ha}\end{array}$ & 3,7 & 0,81 & 1,5 & 0,82 & 0,30 & 0,38 & 0,24 & 0,16 & 0,23 \\
\hline $\begin{array}{l}\mathrm{NH}_{4}{ }^{+}-\mathrm{N}, \\
\mathrm{kg} / \mathrm{ha}\end{array}$ & 0,14 & 0,12 & 0,15 & 0,13 & 0,11 & 0,11 & 0,22 & 0,17 & 0,15 \\
\hline
\end{tabular}

\section{Liukoinen fosfori lisääntyy kasvipeitteisillä mailla}

Liukoinen fosfori käyttäytyi päinvastoin kuin eroosioaines ja PP. Sen kuormitus oli suurinta laitumella ja suorakylvössä. Laidunnettaessa liuk-P-kuorma oli $0,44 \mathrm{~kg} / \mathrm{ha} / \mathrm{v}$ ja suojakaista vähensi sitä $18-36 \%$. Luonnonkaistalla kuormitus oli pienempi, johon saattoi vaikuttaa $17 \%$ pienempi pintavalunta. Liuk- P oli todennäköisesti peräisin P-pitoisesta lannoitteesta (P:a 6 kg/ha 3 vuoden aikana), laiduntavien lehmien sonnasta sekä kasvipeitteestä, josta vapautuu fosforia jäätymisen ja sulamisen seurauksena (Uusi-Kämppä ym. 2012).

Liuk-P:n kuorma (0,5-0,9 kg/ha) oli suuri jo keväällä 2003, ennen kuin laidunnus oli aloitettu (Uusi-Kämppä ja Jauhiainen 2010). Tähän saattoi olla syynä edellisen vuoden lämmin ja vähäsateinen kasvukausi, joka jatkui pitkälle syksyyn. Ensilumi satoi syys-lokakuun vaihteessa ja se kesti pitkän aikaa maassa. Kasvit eivät ilmeisesti olleet vielä varautuneet äkilliseen talven tuloon. Myös laitumen glyfosaattiruiskutusta seuraavana keväänä pintavalunnasta mitattiin suuri määrä liukoista fosforia $(0,6$ $\mathrm{kg} / \mathrm{ha}$ ).

Suorakylvössä liukoisen P:n kuormitus oli pienempi kuin laidunnettaessa. Suojakaistoilla ei ollut vaikutusta liuk-P-kuormitukseen suorakylvössä. Pienin liuk-P:n kuorma $(0,15 \mathrm{~kg} / \mathrm{ha} / \mathrm{v})$ oli 'ei suojakaistaa' -ruudulla silloin, kun maa kynnettiin syksyllä ja muokattiin keväällä. Niitetyllä nurmikaistalla kuormitus oli sama kuin ilman suojakaistaa viljeltäessä. Sen sijaan hoitamaton luonnonkasvikaista lisäsi kuormitusta $60 \%$ perinteisesti muokatulla maalla (Uusi-Kämppä ja Jauhiainen 2010). Ero oli tilastollisesti merkitsevä kevään valumavesissä. Ilmeisesti kasvien keräämästä fosforista osa vapautui kevään sulamisvesiin pakkasen hajottamista kasvisoluista (Uusi-Kämppä 2012, Uusi-Kämppä ym. 2012). Myös Räty ym. (2010) totesivat maanpäällisessä suojakaistakasvillisuudessa fosforimäärän pienenevän loppusyksyä ja seuraavaa kevättä lähestyttäessä. Yli-Heikkilän (2012) mukaan paras suojavyöhykkeen niittoajankohta on heinä-elokuun vaihteessa, jolloin pellon pintaan jäävä biomassa ja siihen kertyneen fosforin määrä ovat mahdollisimman pieniä.

Suojakaistojen pintamaahan kertyi helppoliukoista fosforia, kun kasvustoa ei niitetty. Kasvit 
pumppasivat juurillaan syvemmistä maakerroksista fosforia, joka kertyi maan pintaan kuolleiden kasvinosien mukana. Fosforipitoisuus kasvoi eniten niittämättömillä luonnonkaistoilla. Koekenttää perustettaessa kyntökerroksen fosforipitoisuus oli $8 \mathrm{mg} / \mathrm{l}$, mutta muutamassa vuodessa pitoisuus kasvoi 2 cm:n pintakerroksessa jopa 12-16 mg/l luonnonkaistalla (Uusi-Kämppä ja Kilpinen 2000). Niitetyillä nurmikaistoilla pintamaan fosforipitoisuus pysyi samana kuin kokeen alussa. Mitä suurempi on pintamaan fosforipitoisuus, sitä enemmän liuk-P:a voi huuhtoutua pintavalunnan mukana pellolta. Suojakaistalta tulee poistaa fosforia niittämällä kasvusto vuosittain. Eniten fosforia suojavyöhykkeeltä voidaan poistaa niittämällä kasvusto kesä-heinäkuun vaihteessa ja korjaamalla niitos, jolloin kasvien fosforimäärä on suurimmillaan (Uusi-Kämppä ja Kilpinen 2000). Kasvuston voi hyödyntää esim. rehuna, biokaasulaitoksen syötteenä tai kompostin raaka-aineena.

\section{Typen huuhtoutuminen}

Typpikuormitus pintavalunnassa oli vähäistä lukuun ottamatta perinteistä viljelyä, jossa kok-Nkuorma oli 6,6 kg/ha/v (Uusi-Kämppä 2010). Suojakaista puolitti kuormituksen, mutta typpeä saattoi huuhtoutua salaojaveteen suojakaistoilla. Suorakylvössä kok-N-kuorma oli $2 \mathrm{~kg} / \mathrm{ha} / \mathrm{v}$, joka oli samaa suuruusluokkaa kuin perinteisessä viljelyssä, kun suojakaista oli käytössä. Suorakylvön suojakaistaruuduilla ja laidunnettaessa kok-N-kuorma jäi alle 2:een $\mathrm{kg} / \mathrm{ha} / \mathrm{v}$.

\section{Johtopäätökset}

Suorakylvöllä voidaan saada samanlaisia vaikutuksia pintavaluntaan kuin suojakaistoilla perinteisesti viljeltäessä (kyntö syksyllä ja kylvömuokkaus keväällä). Näin on eroosioaineksen, partikkelifosforin ja kokonaistypen osalta. Liukoinen fosforin määrä pintavalunnassa puolestaan kasvaa suorakylvössä, monivuotisilla nurmilla ja hoitamattomilla suojavyöhykkeillä. Sen takia myös kokonaisfosforin kuormitus vaihteli eri viljelymenetelmillä ja suojakaistoilla; PP väheni kasvipeitteen ansiosta, mutta liuk-P kasvoi.

Nurmikasvustot tulisi niittää ja niitos korjata heinä-elokuun vaihteessa, jotta maan päällinen biomassa ja sen sisältämä fosforimäärä olisivat mahdollisimman pieniä seuraavana talvena ja keväänä. Näin voidaan vähentää kasvipeitteestä vapautuvaa fosforikuormitusta. Aikaisemmalla niitolla (heinäelokuun vaihteessa) voidaan köyhdyttää suojavyöhykkeen maaperää, kun fosforia poistetaan niitoksen mukana mahdollisimman paljon.

Koska laiduntaminen saattaa tiivistää pintamaata, hiljattain perustettujen suojavyöhykkeiden laiduntamista tulisi välttää. Juottopaikka ja mahdollinen kivennäisten syöttöpiste tulee järjestää laidunnetun suojavyöhykkeen yläreunaan mahdollisimman etäälle vesistöstä. Niitä voi myös siirtää välillä, jolloin samaa paikkaa ei kuormiteta jatkuvasti.

\section{Kirjallisuus}

Rasa, K. \& Eickhorst, T. 2012: Structure and pore system in differently managed clayey surface soil as described by micromorphology and image analysis. Geoderma 173-174: 10-18.

Räty, M., Uusi-Kämppä, J., Yli-Halla, M., Rasa, K., Pietola, L. 2010. Phosphorus and nitrogen cycles in the vegetation of differently managed buffer zones. Nutrient Cycling in Agroecosystems 86 1: 121-132.

Uusi-Kämppä, J. 2010: Effect of outdoor production, slurry management and buffer zones on phosphorus and nitrogen runoff losses from Finnish cattle farms. Doctoral Dissertation. MTT Science 7.

Uusi-Kämppä, J. 2012: Jäätyminen lisää nurmikasvuston fosforihuuhtoumaa - kasvuston korjaaminen pienentää. Julkaisussa: Maataloustieteen Päivät 2012 [verkkojulkaisu]. Suomen Maataloustieteellisen Seuran julkaisuja no 28. Toim. Nina Schulman ja Heini Kauppinen. Viitattu 3.12.2013. Julkaistu 15.1.2012. Saatavilla Internetissä: www.smts.fi (Jäätyminen lisää nurmikasvuston fosforihuuhtoumaa - kasvuston korjaaminen pienentää). ISBN 978-951-9041-56-8.

Uusi-Kämppä, J. \& Jauhiainen, L. 2010. Long-term monitoring of buffer zone efficiency under different cultivation techniques in boreal conditions. Agriculture, Ecosystems and Environment 137: 75-85.

Uusi-Kämppä, J. \& Kilpinen, M. 2000: Suojakaistat ravinnekuormituksen vähentäjänä. Maatalouden tutkimuskeskuksen julkaisuja. Sarja A 83. Jokioinen.

Uusi-Kämppä, J., Turtola, E., Närvänen, A., Jauhiainen, L. \& Uusitalo, R. 2012: Phosphorus mitigation during springtime runoff by amendments applied to grassed soil. Journal of Environmental Quality 41: 420-426. Yli-Heikkilä, K. 2012. Mitigating agricultural phosphorus leaching. The effect of timing in grass harvesting in mitigating wintertime phosphorus leaching. Kandidaatin tutkielma. Tampere University of Applied Sciences. 